\title{
PENGARUH ATRIBUT-ATRIBUT KLALITAS AUDIT TERHADAP KEPUASAN KLIEN (Studi Empiris Pada Perusahaan Perbankan di Kota Medan)
}

\author{
Jadongan Sijabat' \\ Fakultas Ekonami dan Bisnis Universitas HKBP Nommensen, Medan \\ jadangan.sijabat回uhn.ac.id
}

\section{Info Artikel \\ Diterima : 08 September 2020 \\ Revisi : 12 Dktober 2020 \\ Terbit : 30 Desember 2020 \\ Key wards: \\ Audit Quality, Client Satisfaction, Ordinary Least Square.}

\section{Kata Kunci:}

Kualitas Audit, Kepuasan Klien, Ordinary Least Square.

\section{Corresponding Author :}

Jadangan Sijabat, E-mail : jadangan.sijabat国uhn.ac.id

\section{Abstract}

This research is a study about attributes of audit quality. The purpose of this research is to re-examine the effect of attributes of audit quality to client satisfaction as Bhen et al (1997). This research conducted with survey on perception of financial managers or controller, that distributed by mail survey to IOU financial manager of banking in Medan City. Unit analysis are the financial managers or controller of banking. There are fifty five questionaires (55\%) received and analyzed by Drdinari Least Square supported by SPSS I0.00 program. The results showed that some of attributes of audit quality effected client satisfaction. The results showed that there were some different result between this study and Bhen et al. (1997).

\section{Abstrak}

Penelitian ini merupakan penelitian tentang atribu-atribut kualitas audit. Tujuan dari penelitian ini adalah untuk menguji kembali pengaruh atributatribut kualitas audit terhadap kepuasan klien sebagaimana penelitian Bhen et al (1997). Penelitian ini dilakukan dengan survei persepsi manajer keuangan atau knntroler yang disebarkan melalui survey kepada 100 manajer keuangan perusahaan perbankan di Kota Medan. Analisis unit adalah manajer keuangan. Lima puluh lima kuesioner (55\%) diterima dan dianalisis oleh Ordinari Least Square didukung program SPSS I0.00.

Hasil penelitian menunjukkan bahwa beberapa atribut kualitas audit berpengaruh terhadap kepuasan klien. Hasil penelitian menunjukkan bahwa terdapat perbedaan hasil antara penelitian ini dengan Bhen et al. (1997). 


\section{PENDAHULUAN}

Perkembangan lingkungan bisnis yang terjadi pada akhir-akhir ini ditunjukkan dengan semakin berkembang dan meningkatnya bisnis sektor jasa. Industri sektor jasa sangat berperan dalam mendukung kemajuan perekonamian suatu Negara. Seperti yang dinyatakan Koepp dalam Widagda, dkk (2002) bahwa industri di sektor jasa akan meningkat secara berkelanjutan dan mencapai batas yang dapat mendaminasi pereknnomian suatu Negara.

Banyak pihak yang tertarik untuk melihat lebih jauh lagi tentang bisnis di sektor jasa ini, ketertarikan tersebut dicurahkan dalam masalah-masalah seperti kualitas jasa (Sutton, 1993; Parasuraman et. al., 1994) dan masalah kepuasan konsumen pengguna jasa (Crane, 1991; Bhen et. al., 1997). Dleh karena itu, penting sekali untuk mengetahui harapan mereka dan hal-hal yang membuat mereka puas atau tidak puas. Kesemuanya ini dapat dengan mudah didapatkan jawabannya dengan melalui suatu riset pelanggan atau klien (Handi Irawan, 2000).

Kantar Akuntan Publik (KAP) merupakan suatu arganisasi bisnis yang bergerak di sektor jasa. KAP merupakan dunia industri yang relatif kampetitif. Lingkungan eksternal audit dicirikan oleh kampetisi yang intens, tekanan fee dan pertumbuhan yang lambat (Elliot dan Jacobsan 1994). Untuk berkampetisi secara sukses dalam lingkungan tersebut KAP harus secara kntinyu berusaha keras untuk melampaui harapan klien dan memaksimalkan kepuasan klien dengan cara memahami faktor penentu kepuasan klien (Purwono, 2011).

Untuk mengetahui kepuasan klien diperlukan tolak ukur, yaitu: bilamana tercapainya keseimbangan dari apa yang diharapkan dengan apa yang dirasakan, misalnya dalam mengkansumsi jasa, bila sesuatu yang dirasakan oleh pelanggan itu melebihi harapan mereka maka ia akan puas. Untuk menilai sesuatu yang dirasakan, ukuran kualitas merupakan salah satu kriteria yang digunakan sebagai bahan pertimbangan. Kepuasan pada dasarnya meliputi tiga hal yaitu kualitas yang dirasakan, nilai yang dirasakan, dan harapan pelanggan (Fornell 1996).

Kualitas audit dapat memberikan penjelasan mengenai atribut-atribut yang menentukan kepuasan klien (Fadhlurokhman dan Nurdhiana, 2009). Tetapi berbagai pendapat mengambil kesimpulan bahwa kualitas pelayanan audit dan kepuasan klien merupakan sesuatu yang berdiri sendiri. Sebagaimana yang dikemukakan oleh Tailor dan Baker (1994), adanya kesepakatan diantara peneliti pemasaran bahwa kualitas pelayanan dan kepuasan klien/konsumen adalah konstruk yang berbeda tetapi memiliki hubungan yang dekat.

Sebagian besar studi yang pernah dilakukan dalam rangka mengevaluasi kualitas audit, selalu membuat kesimpulan dari sudut pandang auditar. Pandangan seperti ini dikemukakan antara lain oleh Mack dan Samet (1982), Sutton (1993) dan juga Schoroeder (1986) dengan fokus pimpinan tim audit. Sementar itu, Carcello et al. (1992) berusaha lebih luas dengan memasukkan orang - orang yang menyiapkan laparan keuangan dan pengguna laparan keuangan sebagai bagian dari atribut kualitas audit. Dengan memasukkan faktor-faktor tersebut maka Carcello et al. telah memberikan informasi lebih menyeluruh mengenai kualitas audit dari sudut pandang klien.

Bhen pada tahun 1997 juga mengadakan penelitian yang sama tentang atribut kualitas audit dengan melihat apakah atribut kualitas audit mempunyai hubungan secara langsung dengan kepuasan klien dengan menggunakan 12 faktar kualitas audit yang dikembangkan oleh Carcelloet al. yang meliputi : pengalaman tim audit dan KAP dalam melakukan pemeriksaan laparan keuangan klien; keahlian/ pemahaman terhadap industri klien; respansif atas kebutuhan klien; kompetensi anggata anggata tim audit terhadap prinsip-prinsip akuntansi dan norma-narma pemeriksaan; sikap independensi dalam segala hal dari individu-individu tim audit dan KAP; 
anggata tim audit sebagai suatu kelompok yang bersifat hati-hati; KAP memiliki komitmen yang kuat terhadap kualitas; keterlibatan pimpinan KAP dalam pelaksanaan audit; keterlibatan komite audit sebelum, pada saat, dan sesudah audit; standar-standar etika yang tinggi dari anggata anggata tim audit; menjaga sikap skeptis dari anggata-anggata tim audit. Dari 12 belas faktar tersebut ditemukan adanya beberapa faktor yang memiliki hubungan positif dengan kepuasan klien yaitu faktor pengalaman, memahami industri klien, respon atas kebutuhan klien, taat pada standar umum, keterlibatan pimpinan KAP, dan komite audit.

Perusahaan perbankan merupakan perusahaan yang sering menggunakan jasa audit dalam upaya mengetahui knndisi perusahaan. Pemilihan perusahaan perbankan sebagai objek penelitian ini dengan pertimbangan bahwa perusahaan tersebut lebih kompleks dilihat dari pangsa pasar yang lebih besar, dan karyawan yang banyak sehingga representatif sebagai responden.

Penelitian ini pada dasarnya sama dengan penelitian yang dilakukan oleh Bhen et al. (1997). Alasan untuk menguji kembali penelitian yang dilakukan oleh Bhen et al (1997) adalah karena kebanyakan penelitian di Indanesia hanya menggunakan 6 instrumen yang sudah terbukti dan tidak melakukan pengujian ulang atas 6 instrumen lainnya yang tidak terbukti. Penelitian ulang atas 12 instumen yang dilakukan oleh Bhen et al. (1997) diperlukan untuk mengetahui apakah dengan sampel yang berbeda dan waktu yang berbeda akan memberikan hasil yang sama dengan peneliti terdahulu. Dengan demikian, adapun yang menjadi tujuan penelitian ini adalah menganalisis pengaruh atribut-atribut kualitas audit terhadap kepuasan klien pada perusahaan perbankan di kota Medan.

\section{URAIAN TEDRITIS DAN HIPOTESIS Kepuasan Pelanggan/Klien}

Pada hakikatnya tujuan bisnis adalah untuk menciptakan dan mempertahankan para pelanggan. Dalam pendekatan TQM, kualitas ditentukan oleh pelanggan. Dleh karena itu hanya dengan memahami proses dan pelanggan maka organisasi dapat menyadari dan menghargai makna kualitas. Adanya kepuasan pelanggan dapat memberikan beberapa manfaat. Beberapa diantaranya: hubungan antara perusahaan dan para pelanggannya menjadi harmonis, memberikan dasar yang baik bagi pembelian ulang, dapat mendarang terciptanya layalitas pelanggan, membentuk suatu rekamendasi dari mulut ke mulut yang menguntungkan bagi perusahaan, reputasi perusahaan menjadi baik di mata pelanggan, dan laba yang diperoleh dapat meningkat (Fandy Tjiptono, 1994).

Kepuasan pelanggan/klien adalah tingkat perasaan sesearang setelah membandingkan kinerja atau hasil yang dirasakan dengan harapannya (Philip Kotler, 1994). Jadi tingkat kepuasan merupakan fungsi dari perbedaan antara kinerja yang dirasakan dan harapan yang diinginkan. Apabila kinerja di bawah harapan maka pelanggan kecewa. Bila kinerja sesuai dengan harapan pelanggan maka akan puas.

Untuk mengetahui kepuasan pelanggan perlu tolak ukur, yaitu: bilamana tercapainya keseimbangan dari apa yang diharapkan dengan apa yang dirasakan, misalnya dalam mengkansumsi jasa. Bila sesuatu yang dirasakan oleh pelanggan itu melebihi harapan mereka maka ia akan puas. Untuk menilai sesuatu yang dirasakan, ukuran kualitas merupakan salah satu kriteria yang digunakan sebagai bahan pertimbangan. Kepuasan pada dasarnya meliputi tiga hal yaitu kualitas yang dirasakan, nilai yang dirasakan, dan harapan pelanggan (Fornell, 1996). 
Kualitas yang dirasakan pelanggan diperoleh melalui pengalaman dari mengkonsumsi barang atau jasa. Konsumen akan terkesan dan merespon atas apa yang dialami termasuk dalam hal mengkonsumsi barang dan jasa. Nilai yang dirasakan atas kualitas jasa akan terkait dengan harapan yang melekat pada diri pelanggan. Nilai tersebut meliputi nilai produk, layanan, nilai karyawan dan citra (Woodruf, 1997). Nilai produk dipengaruhi oleh kualitas dan kelebihan pada jasa seperti keunikan, sedangkan nilai pelayanan terkait fasilitas dan kemudahan yang ditawarkan serta informasi yang memudahkan. Nilai karyawan ditunjukkan dari kemampuan memberikan pelayanan, citra dipengaruhi persepsi pelanggan terhadap kinerja.

\section{Kualitas Audit}

Suatu hal yang tidak dapat disangkal lagi bahwa kualitas produk adalah kunci keberhasilan suatu organisasi. Kemampuan suatu organisasi menghasilkan produk barang maupun jasa yang bermutu tinggi merupakan kunci sukses bagi keberhasilan masa datang (Tatang, 1995).

Parasuraman (1985) menyatakan ada 2 atribut utama yang mempengaruhi kualitas jasa yaitu expected service dan perceived service. Apabila jasa yang diterima atau dirasakan sudah sesuai dengan yang diharapkan maka kualitas jasa dipersepsikan baik dan memuaskan. Jika jasa yang diterima melampaui harapan pelanggan maka kualitas jasa dipersepsikan sebagai kualitas yang ideal. Sebaliknya, jika kualitas jasa yang diperoleh lebih rendah dari harapan pelanggan maka kualitas jasa buruk. Dengan demikian baik tidaknya kualitas jasa tergantung pada kemampuan penyedia jasa dalam memenuhi harapan pelanggannya secara konsisten.

Dalam situasi yang berlainan kualitas diartikan secara berbeda-beda. Menurut Garvin (1990) dalam J. Supranto (1995) ada lima macam perspektif kualitas yang berkembang. Kelima perspektif inilah yang bisa menjelaskan mengapa kualitas diartikan secara berbeda-beda. Kelima perspektif itu adalah: (I) Trancedental appraach, pendekatan ini memandang bahwa kualitas sebagai innate excellence, dimana kualitas dapat dirasakan atau diketahui tetapi sulit didefinisikan dan dioperasionalkan. Sudut pandang ini biasanya diterapkan dalam dunia seni, (2) Praduct based appraach, pendekatan ini menganggap bahwa kualitas merupakan karakteristik atau atribut yang dapat dikuantitatifkan dan dapat diukur, (3) User based appraach, pendekatan ini didasarkan pada pemikiran bahwa kualitas tergantung pada orang yang memandangnya, sehingga produk yang paling memuaskan preferensi sesearang merupakan produk yang berkualitas paling tinggi. (4) Manufacturing based appraach, pendekatan ini bersifat suply-based dan terutama memperhatikan praktik-praktik perekayasaan dan pemanufakturan, serta mendefinisikan kualitas sebagai kesesuaian atau sama dengan persyaratan. (5) Value based appraachpendekatan ini memandang kualitas dari segi nilai dan harga.

\section{Kualitas Audit dan Kepuasan Konsumen/Klien}

Berbagai literatur marketing telah menggambarkan adanya sisi yang berbeda antara kualitas produk dengan kepuasan kansumen. Sisi berbeda tersebut juga bisa didapatkan pada berbagai literatur yang membahas tentang pelayanan profesi atau jasa. Hall dan Elliat (1993) menyatakan bahwa konstruk kualitas pelayanan sering dilihat memiliki hubungan erat dengan kepuasan konsumen atau klien. Padahal keduanya berdiri pada sisi yang berbeda.

Penelitian tentang hubungan kualitas audit dengan kepuasan klien telah banyak dilakukan. Namun, itu belum mampu menjawab kebutuhan saat ini. Pertanyaan selalu timbul adalah benarkah kualitas audit mempengaruhi kepuasan klien? Apa saja atribut kualitas audit tersebut? Penelitian Behn et al (1997) mencoba menjawab 
pertanyaan tersebut dengan menghubungkan kualitas audit dengan kepuasan klien. Ada IZ faktar kualitas audit yang digunakan oleh Bhen dalam penelitiannya, yaitu:

1. Pengalaman Melakukan Audit. Pencapaian keahlian dimulai dengan pendidikan formalnya yang diperluas melalui pengalaman-pengalaman selanjutnya dalam praktik audit (SPAP, SA Seksi 210, 200I). Pengalaman dalam praktik audit juga dipersyaratkan terhadap Asisten Junior. Asisten Junior, yang baru masuk ke dalam karier auditing harus memperoleh pengalaman profesionalnya dengan supervisi yang memadai dan review atas pekerjaannya dari atasannya yang lebih berpengalaman. Pengalaman merupakan atribut yang penting yang dimiliki oleh auditor. Hal ini terbukti dengan tingkat kesalahan yang dibuat oleh auditor yang tidak berpengalaman lebih banyak dari pada auditar yang berpengalaman (Neni widiawati, 200I). Hasil penelitian yang dilakukan Brouwman dan Bradley 1997 dalam Muhammad Ishak (2000) menemukan bukti bahwa penggunaan faktor pengalaman sehubungan dengan kualitas didasarkan pada asumsi bahwa tugas memberikan feedback yang berguna terhadap bagaimana sesuatu dilakukan secara lebih baik, yang diperlukan oleh pembuat keputusan untuk memperbaiki kinerjanya. Disisi lain, Tubs (1992) mengatakan bahwa auditor yang bepengalaman akan memiliki keunggulan dalam hal mendeteksi kesalahan, memahami kesalahan secara akurat, dan mencari penyebab kesalahan.

2. Memahami Industri Klien. Auditor harus memperoleh pengetahuan mengenai hal-hal yang berkaitan dengan sifat bisnis satuan usaha, arganisasinya, dan karakteristik operasinya. Hal-hal tersebut mencakup tipe bisnis, tipe produk dan jasa, struktur modal, pihak yang mempunyai hubungan yang istimewa, lokasi, dan metade produksi, distribusi, serta kompensasi. Auditar juga harus mempertimbangkan hal-hal yang mempengaruhi industri tempat operasi satuan usaha, seperti kondisi ekanomi, peraturan pemerintah, serta perubahan teknologi, yang berpengaruh terhadap auditnya. Hal lain yang harus dipertimbangkan oleh auditor adalah praktek akuntansi yang umum berlaku dalam industri, knndisi persaingan, dan ratio keuangan (SPAP, 20DI). Memahami bisnis klien berarti memperkecil resikn audit sebab memahami industri klien menjadi bagian integral yang tak terpisahkan dengan pekerjaan profesi. Sehingga hasil audit yang dihasilkan dapat memenuhi standar mutu auditing (Наггу Suharto, 2000). Selain dapat membuat audit lebih berkualitas, memahami industri klien juga berguna untuk memberi masukan agar klien beroperasi secara lebih efisien (Wolk dan Wouton, 1997). Keunggulan tersebut akan bermanfaat bagi klien untuk melakukan perbaikan-perbaikan dan akan memberikan kepuasan bagi klien.

3. Respansif atas Kebutuhan Klien. Yang dimaksud dengan responsif atas kebutuhan klien adalah klien berharap menerima lebih banyak daripada hanya opini audit klien, dan juga ingin mendapat keuntungan dari keahlian dan pengetahuan auditar di bidang usaha dan memberi nasehat tanpa diminta (Wahoney dalam Widagda dkk, 2002). Ketika kantor akuntan publik melakukan audit terhadap suatu perusahaan, maka opini menjadi sentral perhatian. Padahal klien membutuhkan banyak hal lainnya, tidak sekedar opini. Klien berharap selain menerima opini audit, juga ingin mendapatkan keuntungan dari keahlian dan pengetahuan auditor di bidang usaha dan memberikan nasehat tanpa diminta. Mahon (1982) dalam suatu interview oleh pihak klien-kliennya, menyimpulkan bahwa faktor yang membuat klien memutuskan pilihannya terhadap suatu KAP adalah kesungguhan KAP tersebut memperhatikan kebutuhan kliennya. Adanya keunggulan ini akan memberikan kepuasan bagi klien. 
4. Taat Pada Standar Umum. Standar umum bersifat pribadi dan berkaitan dengan persyaratan auditor dan mutu pekerjaannya, dan berbeda dengan standar yang berkaitan dengan pelaksanaan pekerjaan lapangan dan pelaporan auditor (SPAP, 20D). Syarat utama untuk menjadi seorang auditor adalah ia harus memiliki latar belakang pendidikan formal akuntansi dan auditing serta berpengalaman baik secara langsung maupun tidak langsung dalam bidang auditing (Media Akuntansi, 200I).

5. Independensi Tim Audit. Kepercayaan masyarakat umum atas independensi sikap auditor sangat penting bagi perkembangan profesi akuntan publik. Kepercayaan masyarakat akan menurun jika terdapat bukti bahwa independensi sikap auditar ternyata berkurang. Sikap independensi bermakna bahwa auditor tidak mudah dipengaruhi (SPAP, 20DI), sehingga auditor akan melaparkan apa yang ditemukannya selama proses pelaksanaan audit.

6. Sikap Hati-Hati. Kehati-hatian profesional mengharuskan anggota untuk memenuhi tanggung jawab profesionalnya dengan kampetensi dan ketekunan. Hal ini mengandung arti bahwa anggota mempunyai kewajiban untuk melaksanakan jasa profesional dengan sebaik-baiknya sesuai dengan kemampuannya (Neni Widiawati, 200I). Kesalahan dapat dideteksi jika auditor memiliki keahlian dan kecermatan. Ahli diartikan sebagai ahli akuntansi dan audit (SPAP, 20DI) dan cermat menekankan pada pencarian tipe-tipe kesalahan yang mungkin ada melalui sikap hati-hati (Mautz dan sharaf, 1961).

7. Komitmen yang Kuat Terhadap Kualitas Audit. Komitmen dapat didefinisikan sebagai (I) sebuah kepercayaan pada dan penerimaan terhadap tujuan-tujuan dari nilai-nilai organisasi dan atau profesi, (2) sebuah kemauan untuk menggunakan usaha yang sungguh-sungguh guna kepentingan organisasi dan atau profesi, (3) sebuah keinginan untuk memelihara keanggataan dalam organisasi dan atau profesi (Araya et al. 1980). Akuntan publik di Indonesiamewajibkan para anggotanya untuk mengikuti program pendidikan profesi berkelanjutan dan untuk menjadi anggata baru harus mengikuti program profesi akuntan (PPA) agar kerja auditnya berkualitas, hal ini menunjukkan kamitmen yang kuat dari IAI dan para anggatanya (Widagda, 2002). Auditor dalam melaksanakan kerjanya harus meningkatkan kordinasi dan hubunganya dengan KAP besar dan bersakala internasional. Dengan demikian, diharapkan auditor akan mampu menyajikan informasi-informasi yang sedang berkembang di berbagai negara. Terutama yang ada hubunganya dengan bidang usaha klien. Sehingga kualitas kerja auditar akan meningkat selaras dengan peningkatan pengetahuannya yang lintas negara, hal ini berkaitan erat dengan komitmen yang kuat searang auditor terhadap kualitas audit (Bhen et al. 1997).

8. Keterlibatan Pimpinan KAP. Pakar mutu terkenal W. Edwards Deming menyebutkan bahwa 80 persen masalah mutu merupakan masalah manajemen (Widagda, 2002). Tanpa keterlibatan manajemen, manajemen mutu hanya menjadi konsep yang kabur dan hampir mustahil diimplementasikan secara efektif. Keberhasilan manajemen mutu memerlukan kepemimpinan yang efektif, baik secara farmal (berdasarkan hirarki organisasi) maupun yang kurang/tak formal. Pemimpin yang baik perlu menjadi faca/ point yang mampu memberikan perspektif dan visi luas atas kegiatan perbaikan serta mampu memativasi, mengakui dan menghargai upaya dan prestasi perorangan maupun kelompok (Tatang dalam Widagda, 2002).

9. Melakukan Audit Lapangan Dengan Tepat. Standar pekerjaan lapangan pertama mengharuskan bahwa "pekerjaan harus direncanakan sebaik-baiknya dan jika digunakan asisten harus disupervisi dengan 
semestinya". Dalam perencanaan auditnya, auditor harus mempertimbangkan sifat, luas, dan saat pekerjaan yang harus dilaksanakan dan membuat suatu program audit secara tertulis (SPAP, 20DI).

何. Keterlibatan Komite Audit. Komite audit diperlukan dalam suatu organisasi bisnis antara lain dikarenakan mengawasi proses audit dan memungkinkan terwujudnya kejujuran pelaparan keuangan. Namun, hal ini dapat dicapai jika kamite audit bekerja secara efektif (Menon dan Williams, 1994). Praktek yang terbaik yang dapat dilakukan KAP untuk menjaga independensi dan profesionalismenya jika berhadapan dengan ketepatan penggunaan prinsip-prinsip akuntansi oleh klien adalah dengan melakukan komunikasi dengan dewan direksi atau komite audit (Glazer dan Febian, 1997). Melibatkan komite audit dalam pelaksanaan audit dapat membantu auditor. Oleh karenanya, banyak KAP yang membantu kliennya dalam pembentukan kamite audit (Menon dan William, 1994).

11. Standar Etika yang Tinggi. Etika adalah (I) ilmu tentang apa yang baik dan apa yang buruk dan tentang hak dan kewajiban moral (akhlak), (2) Kumpulan asas atau nilai yang berkenaan dengan akhlak, (3) nilai mengenai benar dan salah yang dianut suatu golongan atau masyarakat (Neni Widiawati, 200I). Dalam usaha untuk meningkatkan akuntabilitasnya searang auditor harus menegakkan etika profesional yang tinggi, agar timbul kepercayaan dari masyarakat. Audit yang berkualitas sangat penting untuk menjamin bahwa profesi akuntan memenuhi tanggung jawabnya kepada investor, masyarakat umum dan pemerintah serta pihak-pihak lain yang mengandalkan kredibilitas laparan keuangan yang telah diaudit (H.S Munawir, 1997).

12. Menjaga Sikap Skeptisme. Audit atas laparan keuangan berdasarkan atas standar auditing yang ditetapkan Ikatan Akuntan Indanesia harus direncanakan dan dilaksanakan dengan sikap skeptisme profesional (SPAP, 20DI). Hal ini mengandung arti bahwa auditor tidak boleh menganggap manajemen sebagai orang yang tidak jujur, namun juga tidak boleh menganggap bahwa manajemen sebagai arang yang tidak diragukan lagi kejujuranya.

\section{KERANGKA PEMIKIRAN TEDRITIS DAN HIPOTESIS}

Kajian literatur dan hasil penelitian sebelumnya menjadi landasan teoritis bagi peneliti untuk mengembangkan model kerangka pemikiran teoritis seperti dalam gambar l. 


\section{Gambar I Kerangka Pemikiran Tearitis: Hubungan Atribut-Atribut Kualitas Audit Dengan Kepuasan} Klien

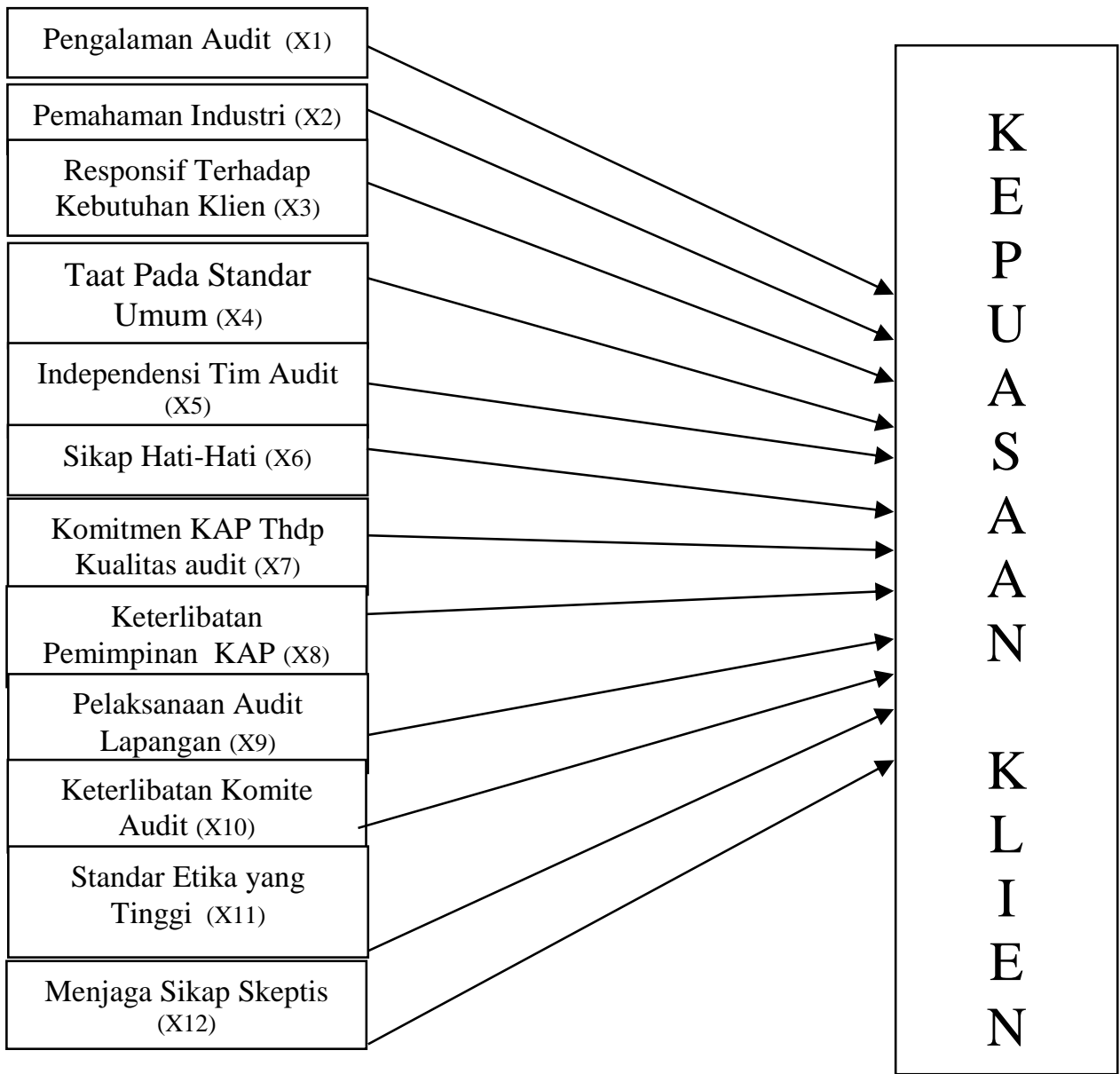

Kualitas Audit dalam model tersebut merupakan variabel independen yang mempunyai hubungan positif dengan kepuasan klien (variabel dependen). Selanjutnya, sesuai dengan gambar tersebut, peneliti mengajukan hipatesis mengenai hubungan kedua variabel tersebut dengan rumusan sebagai berikut :

HI : Atribut-atribut kualitas audit berpengaruh positif terhadap kepuasan klien.

\section{METODE PENELITIAN}

\section{Populasi dan Sampel}

Populasi dalam penelitian ini adalah seluruh manajer keuangan/ cantroller perusahaan perbankan di kota Medan. Metade sampling yang digunakan dalam penelitian ini adalah randam sampling dengan pertimbangan jumlah populasi yang kecil dan tingkat respanse rate yang rendah. Untuk mendapatkan data yang diperlukan, kuesioner diantar langsung kepada responden. Respondennya adalah para manajer keuangan atau contraller.

Alasan peneliti menggunakan manajer keuangan/cantraller sebagai respanden yang menjawab kuesioner penelitian ini adalah karena controller/manajer keuangan memiliki informasi lengkap dan menyeluruh untuk mengevaluasi kinerja KAP, sebab mereka selalu berhubungan dengan KAP apabila perusahaanya diaudit. 


\section{Definisi Dperasional Variabel}

Kualitas audit yang mengacu pada kualitas jasa merupakan ciri atu sifat dari suatu jasa yang dapat berpengaruh pada kemampuannya untuk memberikan kebutuhan akan kepuasan konsumen/klien (Kotler,1997). Instrumen kualitas audit dalam penelitian ini menggunakan instrumen yang dikembangkan oleh Bhen et.al. (1997) yang terdiri 12 item pertanyaan.

Kepuasan pelanggan adalah tingkat perasaan sesenrang setelah membandingkan kinerja atau hasil yang dirasakan dengan harapannya (Kotler, 1994). Kepuasan dalam penelitian ini adalah kepuasan dari para manajer keuangan perusahaan perbankkan di kota Medan atas hasil audit yang diberikan oleh Kantar Akuntan Publik. Instrumen yang digunakan dalam penelitian ini adalah instrumen yang dikembangkan oleh Bhen (1997) yang terdiri dari $Z$ item pertanyaan.

\section{HASIL PENELITIAN DAN PEMBAHASAN}

\section{Gambaran Umum Responden}

Ringkasan pengiriman dan pengembalian kuisioner dalam penelitian ini ditunjukkan dalam tabel I berikut.

Tabel I. Rincian Pengiriman dan Penerimaan Kuesioner

\begin{tabular}{|c|c|}
\hline Pengiriman kuesioner & 100 \\
\hline Kuisioner yang kembali & 55 \\
\hline Tingkat pengembalian (respanse rate) $\quad$ ( 55 / 100 * 100\% ) & $55 \%$ \\
\hline Kuisioner yang kembali, tetapi tidak dapat dialah & ] \\
\hline Kuisioner yang dapat diolah & 55 \\
\hline
\end{tabular}

Sumber : Data primer diolah, 2020

Adapun profil dari 55 responden ditunjukkan pada tabel 2 berikut.

Tabel 2. Profil Responden ( $n=55)$

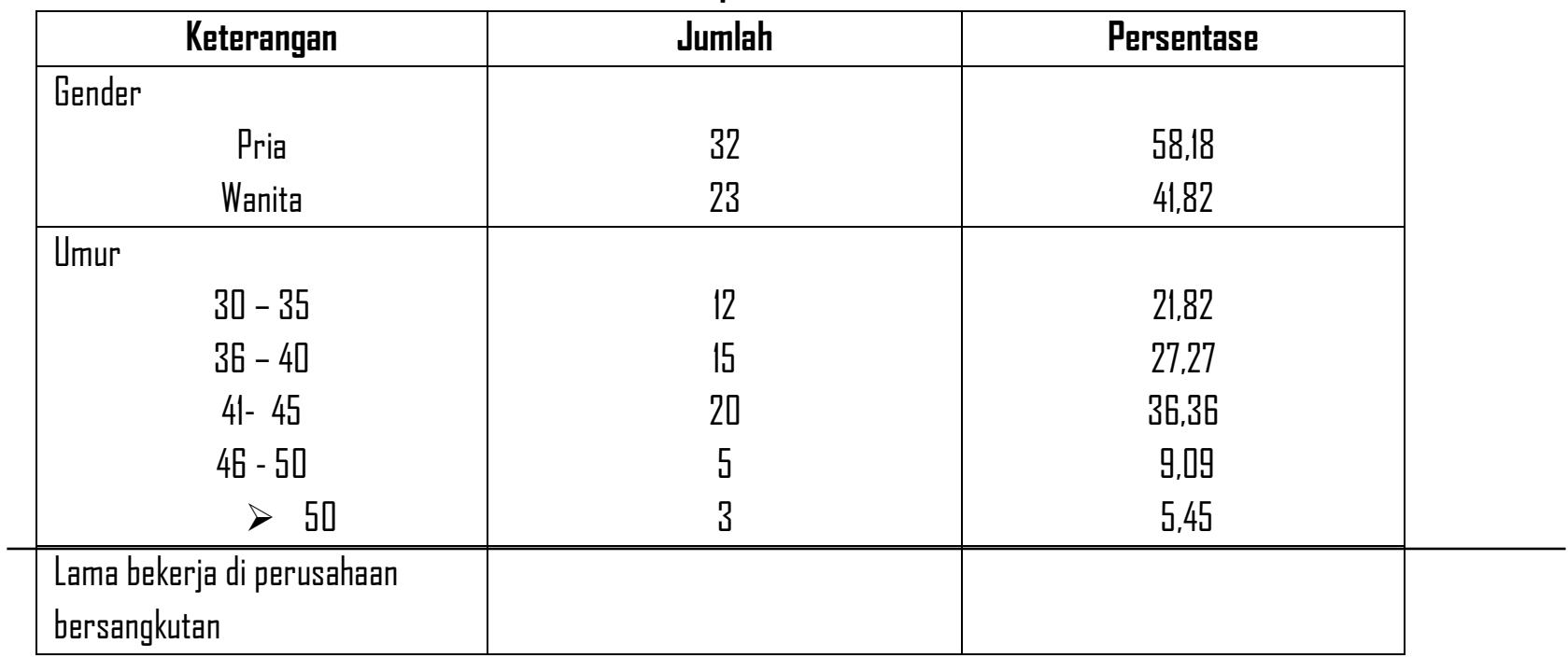




\begin{tabular}{|c|c|c|}
\hline $1-5$ & 15 & 27,27 \\
$6-10$ & 30 & 54,54 \\
$>10$ & 10 & 18,18 \\
\hline Lama jabatan di perusahaan yang & & \\
bersangkutan & & \\
$1-5$ & 35 & 63,63 \\
$6-10$ & 18 & 32,72 \\
$>10$ & 2 & 3,63 \\
\hline
\end{tabular}

Sumber : Hasil Penelitian, 2020

\section{Statistik Diskriptif}

Untuk memberikan gambaran mengenai variabel-variabel penelitian (Kualitas Audit, Kepuasan klien) digunakan tabel statistik deskriptif yang menunjukkan angka kisaran teoritis dan sesungguhnya, rata-rata, dan standar deviasi yang dapat dilihat dalam tabel 3 berikut.

Tabel 3. Statistik Deskriptif Variabel Penelitian

\begin{tabular}{|l|c|c|c|c|}
\hline \multicolumn{1}{|c|}{ Variabel } & Kisaran Tearitis & $\begin{array}{c}\text { Kisaran } \\
\text { Sesungguhnya }\end{array}$ & Rata-rata & $\begin{array}{c}\text { Standar } \\
\text { Deviasi }\end{array}$ \\
\hline Kualitas audit Kepuasan & $12-60$ & $24-56$ & 44,29 & 6,46 \\
klien & $2-10$ & $4-10$ & 7,46 & 1,54 \\
\hline
\end{tabular}

Sumber : Hasil Penelitian, 2020

Berdasarkan tabel diatas, pengukuran variabel kualitas audit, kisaran jawaban responden mendekati kisaran teoritisnya, dengan nilai rata-ratanya 44,29 dan standart deviasi 6,46. Hal ini berarti bahwa jawaban responden agak menyebar kedalam lima kategari, tetapi cenderung memiliki tingkat jawaban kualitas audit yang relatif tinggi, yang ditunjukkan nilai rata-rata yang mendekati nilai maksimum kisaran sesungguhnya. Pada variabel kepuasan klien kisaran jawaban responden mendekati kisaran teoritisnya dengan nilai rata-rata 7,46 dan standar deviasi 1,54. Maknanya adalah responden menyebar dalam lima kategori, tetapi cenderung memiliki kepuasan klien yang relatif tinggi, yang ditunjukkan oleh nilai rata-rata yang mendekati nilai maksimum kisaran yang sesungguhnya. Hal ini berarti tidak ada manajer keuangan/controller yang menjadi responden dalam penelitian ini yang memiliki tingkat kepuasan pada tingkat ekstrim (rendah atau tinggi).

\section{Uji Realibilitas dan Validitas}

لji Reliabilitas digunakan untuk mengukur suatu kuesioner yang merupakan indikator dari variabel atau knnstruk. Suatu kuesioner dikatakan reliabel atau handal jika jawaban sesearang terhadap pernyataan adalah konsisten atau stabil dari waktu ke waktu (Imam Ghazali, 2000). Pengukuran dengan one shat atau pengukuran sekali saja digunakan dalam penelitian ini. Suatu konstruk atau variabel dikatakan reliabel, jika memberikan nilai cranbach a/pha> 0,60 (Nunally, 1969 dalam Imam Ghazali, 2001). Hasil pengujian dengan menggunakan program SPSS I0.0 menunjukkan nilai cranbach a/pha instrumen variabel kualitas audit sebesar 0,83 dan instrumen variabel kepuasan klien sebesar 0,76. Artinya instrumen variabel kualitas audit maupun instrumen variabel kepuasan klien adalah handal atau reliabel untuk digunakan dalam pengalahan data. 
Uji validitas digunakan untuk mengukur sah atau valid tidaknya suatu kuesioner. Suatu kuesioner dikatakan valid jika pertanyaan pada kuesioner mampu untuk mengungkapkan sesuatu yang akan diukur oleh kuesioner tersebut. Dalam penelitian ini, untuk mengukur validitas digunakan Caeficient Carrelation Pearsan yaitu dengan menghitung korelasi antara scare masing-masing butir pertanyaan dengan total scare (Imam Chozali, 2000). Variabel kualitas audit terdiri atas 12 item pertanyaan dan variabel kepuasan klien terdiri atas 2 item pertanyaan. Hasil pengujian dengan menggunakan program SPSS 10.0 menunjukkan nilai Carrelation Pearsan masing-masing instrumen yang dapat dilihat pada tabel 4 berikut.

Tabel 4. Validitas Instrumen Kualitas Audit dan Kepuasan Klien

\begin{tabular}{|c|c|c|c|}
\hline Variabel & Item & $\begin{array}{c}\text { Nilai Pearson } \\
\text { Corelation }\end{array}$ & Status \\
\hline \multirow[t]{13}{*}{ Kualitas Audit } & XI & 0,642 & Valid \\
\hline & $x 2$ & 0,863 & Valid \\
\hline & $X 3$ & 0,876 & Valid \\
\hline & $X 4$ & 0,842 & Valid \\
\hline & X5 & 0,325 & Valid \\
\hline & X巨 & 0.454 & Valid \\
\hline & $X 7$ & 0,357 & Valid \\
\hline & $X 8$ & 0,750 & Valid \\
\hline & X马 & 0,257 & Valid \\
\hline & $X 10$ & 0,785 & Valid \\
\hline & XII & 0,553 & Valid \\
\hline & $X 12$ & 0,365 & Valid \\
\hline & $X 13$ & 0,872 & Valid \\
\hline Kepusasan Klien & XI4 & 0,951 & Valid \\
\hline
\end{tabular}

Sumber: Hasil Penelitian, 2020

Dari tabel 4 terlihat bahwa korelasi antara masing-masing skore butir pertanyaan (XI s/d XI2) terhadap total scare butir-butir pertanyaan (kualitas audit) menunjukkan hasil yang signifikan (pada level 0.05). Jadi dapat disimpulkan bahwa masing-masing butir pertanyaan adalah valid. Begitu juga dengan XI3 dan X14 valid menjadi indikator kepuasan klien karena masing-masing item pertanyaan mempunyai nilai korelasi yang signifikan (pada level 0.05) Selanjutnya data yang dikumpulkan dengan instrumen yang valid dalam penelitian ini yang akan dianalisa lebih lanjut. 


\section{Uji Hipotesis}

Dalam penelitian ini hanya terdapat satu hipotesis yang akan diuji yaitu apakah atribut-atribut variabel kualitas audit berpengaruh terhadap kepuasan klien. Pengujian hipatesis dengan menggunakan analisis $0 L S$ (Drdinary Least Squares/pangkat kuadrat terkecil biasa). Dengan melihat tingkat signifikansi $(<0,05)$ dari masing-masing pengaruh atribut kualitas audit terhadap kepuasan klien, maka akan dapat diketahui bahwa hipatesis ini diterima atau ditolak. Dari tabel 5 berikut ini dapat diketahui hasil dari pengujian hipatesis dalam penelitian ini.

Tabel 5. Pengaruh Antara Atribut Kualitas Audit Dengan Kepuasan Klien

\begin{tabular}{|c|c|c|c|}
\hline $\begin{array}{c}\text { Atribut Kualitas } \\
\text { Audit }\end{array}$ & Koeffisien Regresi & R Square & Signifikansi \\
\hline$X 1$ & 1,435 & 0,763 & $0.000^{* * *}$ \\
\hline$X 2$ & 1,791 & 0,852 & $0.000^{* * *}$ \\
\hline$X 3$ & 1,753 & 0,625 & $0.000^{* * *}$ \\
\hline$X 4$ & 1.518 & 0,742 & $0.000^{* * *}$ \\
\hline$X 5$ & 0,565 & 0,025 & 0.125 \\
\hline$X 6$ & 0,342 & 0,024 & 0.213 \\
\hline$X 7$ & 1,459 & 0,242 & $0.000^{* * *}$ \\
\hline$X 8$ & 1,432 & 0,731 & $0.000^{* * *}$ \\
\hline$X 9$ & 0,115 & 0,015 & 0.353 \\
\hline$X 10$ & 1,387 & 0,651 & $0.000^{* * *}$ \\
\hline$X 11$ & 0,032 & 0,012 & 0.650 \\
\hline$X 12$ & 0,291 & 0,014 & 0.070 \\
\hline
\end{tabular}

Sumber : Hasil Penelitian, 2020

Berdasarkan hasil output SPSS versi I0.D dari regresi masing-masing atribut yang menunjukkan hasil yang berbeda-beda pada R square, knefisien regresi, dan tingkat signifikansinya. Pada tabel 5 diatas dapat diketahui hanya ada 7 saja atribut kualitas audit ( yaitu: XI, XZ, X3, X4, X7, X8, XID ) yang berpengaruh terhadap kepuasan klien, sedang yang 5 ( yaitu: X5, XБ, X马, XII, XI2) tidak berpengaruh terhadap kepuasan klien.

\section{HASIL DAN PEMBAHASAN}

Pengujian terhadap hipatesis penelitian ini yang menyatakan bahwa terdapat pengaruh atribut-atribut kualitas audit terhadap kepuasan klien ternyata tidak sepenuhnya terbukti. 
Atribut pengalaman melakukan audit (XI) menunjukkan adanya pengaruh yang positif signifikan terhadap kepuasan klien dengan tingkat signifikansi dibawah 0,05 (p 0,000, R square 0,763 dan koefisien regresi 1,435). Hal ini berarti auditar yang berpengalaman dan yang terkait dengan pelaksanaan audit, akan memberikan kepuasan bagi klien yang sedang diaudit tersebut, karena auditor yang berpengalaman akan memiliki keunggulan dalam hal mendeteksi kesalahan, memahami kesalahan secara akurat, dan mencari penyebab kesalahan (Tubs, 1992).

Atribut memahami industri klien (X2) menunjukkan adanya pengaruh yang positif signifikan terhadap kepuasan klien dengan tingkat signifikansi dibawah 0,05 (р 0,000, R square 0,852 dan koefisien regresi (,79I). Hal ini berarti bahwa pemahaman pihak yang terkait dalam pelaksanaan audit dalam memahami industri klien, akan memberikan kepuasan bagi klien yang sedang diaudit tersebut, sebab dengan memahami industri klien berarti memperkecil resikn audit, sehingga hasil audit yang dihasilkan dapat memenuhi standar mutu auditing (Hari Suharto, 2000).

Atribut responsif terhadap kebutuhan klien (X3) menunjukkan adanya pengaruh positif signifikan terhadap kepuasan klien dengan tingkat signifikansi dibawah 0,05 (p 0,000, R square 0,625 dan koefisien regresi 1,753). Hal ini menunjukkan bahwa klien akan merasa puas apabila auditar KAP responsif akan kebutuhanya, hal ini didukung oleh penelitian yang dilakukan oleh Mahon (1989) yang menyatakan bahwa klien memutuskan pilihannya terhadap suatu KAP adalah karena adanya kesungguhan dari KAP tersebut memperhatikan kebutuhan kliennya.

Atribut pemeriksaan sesuai dengan standar umum audit (X4) menunjukkan adanya pengaruh positif signifikan terhadap kepuasan klien dengan tingkat signifikansi dibawah 0,05 (p 0,000, R square 0,742 dan knefisien regresi I,5l8). Hal ini berarti apabila auditor dalam melaksanakan tugas-tugasnya sudah sesuai dengan standar umum yang telah ditetapkan maka akan memberikan kepuasan bagi klien, seperti yang telah dikatakan oleh Elitzur dan Falk (1996) bahwa kredibilitas auditar tergantung pada kemungkinan auditor mendeteksi kesalahan yang material dan kesalahan penyajian, dan kemungkinan auditor akan melaparkan apa yang ditemukannya. Kedua hal tersebut mencerminkan terlaksananya standar umum dengan adanya kedua hal tersebut akan memberikan kepuasan bagi klien.

Atribut independensi (X5) tidak berpengaruh terhadap kepuasan klien, hal ini dilihat dari tingkat signifikansinya > 0,05 (р 0,125, R square 0,025 dan koefisien regresi 0,565). Hal ini menunjukkan, walaupun auditor yang melaksanakan audit sudah bersikap independen tetapi tidak berpengaruh terhadap kepuasan kliennya, karena klien lebih senang kalau auditor tersebut bisa diajak komunikasi dua arah sesuai dengan yang dinyatakan Bhen et al. (1997).

Atribut sikap hati-hati anggota tim audit (XE) tidak berpengaruh terhadap kepuasan klien, hal ini dilihat dari tingkat signifikansinya > 0.05 (р 0,213, R square 0,024 dan knefisien regresi 0,342). Hal ini menunjukkan bahwa apabila auditor dalam melaksanakan kegiatannya dilakukan dengan hati-hati akan membuat kliennya merasa tidak puas. Hal ini menunjukkan bahwa kemungkinan klien lebih menginginkan auditar bekerja sesuai dengan keinginan klien karena dengan sikap kehati-hatian yang tinggi searang auditar akan sulit untuk diajak berkamunikasi sesuai dengan apa yang diinginkan oleh klien.

Atribut kamitmen kuat terhadap kualitas audit (X7) berpengaruh terhadap kepuasan klien dengan

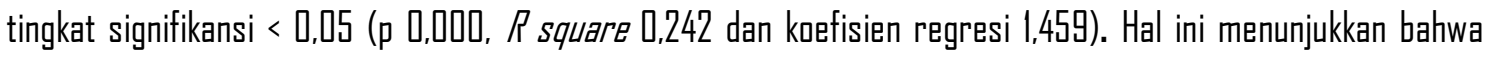
apabila auditor dalam melakukan pekerjaanya menunjukkan adanya komitmen yang kuat terhadap kualitas 
auditnya maka akan memberikan kepuasan bagi kliennya. Hal ini juga didukung oleh lkatan Akuntan Indanesia (IAI) selaku induk organisasi akuntan di Indanesia yang mewajibkan bagi calon anggota baru untuk mengikuti program pendidikan profesi akuntan (PPA), sebab dengan qualiti cantro/PPA, IAI mampu menjamin kualitas audit anggatanya (Наггу Suharto, 2002).

Atribut keterlibatan pimpinan audit terhadap pemeriksaan (XZ) berpengaruh terhadap kepuasan klien hal ini bisa dilihat dari tingkat signifikansinya < 0,05 (р 0,000, R square 0,731 dan koefisien regresi I,43Z). Hal ini berarti apabila auditor yang melaksanakan pekerjaanya didampingi oleh pimpinannya maka hal ini akan memberikan kepuasan bagi klien yang diaudit tersebut, sebab dengan keterlibatan pimpinan dalam melaksanakan audit akan memberikan mativasi terhadap bawahan dan perbaikan atas kegiatan yang dilakukan, akan membuat klien merasa puas Tatang. (1995).

Atribut melakukan pekerjaan lapangan dengan tepat (XS), tidak berpengaruh terhadap kepuasan klien, hal ini bisa dilihat dari tingkat signufikansinya yang diatas 0,05 (p 0,353, R square 0,015 dan kaefisien regresi (1/15). Hal ini berarti apabila auditar melakukan pekerjaan lapanganya dengan tepat akan memberikan ketidak puasan bagi kliennya. Hal ini menunjukkan bahwa kemungkinan klien lebih menginginkan auditar bekerja sesuai dengan keinginan klien dan bisa diajak komunikasi.

Atribut hubungan KAP dengan kamite audit (XID) berpengaruh positif terhadap kepuasan klien

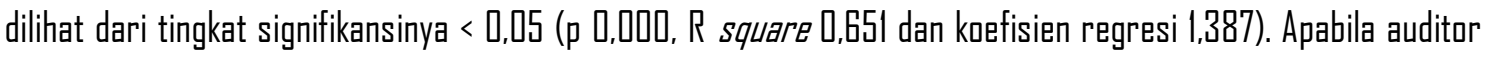
yang melakukan auditnya sering melakukan kontak dengan komite audit perusahaan maka akan memberikan kepuasan bagi klien perusahaan tersebut, sebab praktek yang terbaik yang dapat dilakukan KAP untuk menjaga independensi dan profesionalismenya jika berhadapan dengan ketepatan penggunaan prinsip-prinsip akuntansi oleh klien adalah dengan melakukan komunikasi dengan dewan direksi atau kamite audit (Glazer dan Fabian, 1997).

Atribut standar etika yang tinggi (XII), tidak berpengaruh terhadap kepuasan klien hal dilihat dari signifikansi < 0,05 (p 0,650, R square 0,0IZ, dan koefisien regresi 0,03Z). Hal ini mengandung arti apabila auditor yang melaksanakan pekerjaanya itu mempunyai etika yang tinggi maka akan menimbulkan ketidakpuasan terhadap klien. Hal ini menunjukkan bahwa klien lebih menginginkan auditor bekerja sesuai dengan keinginan klien karena dengan menjunjung etika yang tinggi seorang auditar akan sulit untuk diajak berkamunikasi sesuai dengan apa yang diinginkan oleh klien.

Atribut tidak mudah percaya (XIZ), tidak berpengaruh terhadap kepuasan klien hal ini bisa dilihat dari signifikansi > 0,05 (p 0,070, R square 0,014 dan koefisien regresi 0,291). Hal ini mengandung arti bahwa apabila auditor dalam melaksanakan pekerjaanya itu menunjukkan sikap yang tidak mudah percaya yang tinggi maka, akan menimbulkan ketidak puasan bagi kliennya. Hal ini juga didukung oleh hasil dari Bhen et al (I997), bahwa klien akan merasa tidak puas apabila auditar yang melakukan tugasnya menaruh kecurigaan yang tinggi terhadap kliennya.

Secara umum hasil ini sesuai dengan hasil penelitian Bhen et al (1997) dengan sedikit perbedaan pada penemuan baru atribut (X7) yang menyatakan bahwa komitmen yang kuat terhadap kualitas audit berpengaruh terhadap kepuasan klien. Diterimanya atribut KAP mempunyai kamitmen yang kuat terhadap kualitas audit karena hal ini tidak lepas dari adanya usaha-usaha yang dilakukan oleh IAI (Ikatan Akuntan Indanesia) selama ini 
membuat klien kantar akuntan publik merasa puas adapun usaha yang dilakukan oleh IAI antara lain membuat program bagi para anggotanya yang bekerja di kantor-kantor akuntan publik untuk meningkatkan kualitas auditnya dengan cara mengikuti program profesi berkelanjutan dan hal itu sifatnya wajib, sedang program yang lainya yaitu PPA (Pendidikan Profesi Akuntan) yaitu suatu program yang diperuntukkan bagi calon anggota baru untuk wajib mengikuti program tersebut, dan hal ini merupakan suatu kamitmen yang kuat bagi IAl untuk meningkatkan kualitas anggatanya agar auditnya berkualitas hal ini seperti yang dikemukakan oleh Наггy Suharto (2000) dengan qualiti contro/PPA, IAI mampu menjamin kualitas audit anggotanya.

\section{PENUTUP}

\section{KESIMPULAN}

Berdasarkan pengujian terhadap hipatesis penelitian ini yang menyatakan bahwa terdapat pengaruh antara atribut-atribut kualitas audit terhadap kepuasan klien ternyata tidak sepenuhnya terbukti. Hal ini bisa dilihat dari hasil output SPSS versi I0.D Drdinari Least Square (DLS) masing-masing atribut yang menunjukkan hasil yang berbeda-beda pada, R square, knefisien regresi, dan tingkat signifikansinya, dari hasil diatas terdapat 7 atribut dari kualitas audit yang berpengaruh signifikan dengan kepuasan klien yaitu ( XI, XZ, XZ, X4, X7, X8, XII ) dan ada 5 atribut kualitas audit yang tidak berpengaruh dengan kepuasan klien yaitu ( $X 5, X 5, X$ 马, XII, XIZ). Secara umum hasil ini sesuai dengan hasil penelitian Bhen et al (1997) dengan sedikit perbedaan pada penemuan baru atribut (X7) yang menyatakan bahwa kamitmen yang kuat terhadap kualitas audit berpengaruh terhadap kepuasan klien.

\section{Keterbatasan Penelitian}

Keterbatasan dalam penelitian ini adalah pada jumlah sampel yang kembali sangat minim dan kurang dari sampel minimum yang ditetapkan sehingga sulit untuk menggeneralisasi hasil dari penelitian ini. Data penelitian ini dihasilkan dari instrumen yang mendasarkan pada persepsi jawaban responden. Hal ini akan menimbulkan masalah jika persepsi responden berbeda dengan keadaan yang sesungguhnya. Rekomendasi untuk penelitian yang akan datang disarankan untuk mencoba menambah populasi.

\section{DAFTAR PUSTAKA}

Behn, B.K., Carcellם, J.V., Hermansan D.R., Hermansan, R.H. (1997). The Determinants of Audit Client Satisfaction amang Clients of Big 6 Firms, Accaunting Harizans, (March)Vol. II, No.(I),7-24.

Гrane, F.G. I991. Customer Satisfaction/Disatisfaction With Profesional Services. Jaurna/ af profesiona/ Serces Marketing. Vol. 7 (2): $19-25$.

Elitzur, Ramy and Haim Falk, (1996). Planned Audit Quality, Jaurna/ of Accounting and Public Palicy, vol. 15: 247269.

Elliott, R.K., and P.D. Jacobsan. 1994-95. AICPA. Assurance Services Commite: What is The Future of Auditing ? The لdurna/ of Larparate Accounting and Finance (Winter): 87-97.

Fadhlur okhman dan Nurdhiana, (2009), Pengariuh Atribut-Atribut Kualitas Audit Terhadap Kepuasan Klien, ASET, Val. II, No. 2, September, Hal 141 - 147. 
Fornell et al (1996)," The American Customer Satisfaction Index, Nature Purpose, and Finding," Jaurnal of Marketing, Oktober Vol, 60, p.7-18,

Glazer, Alan S. and Sheri L. Fabian (1997). Best Practices far CPA Firms, Jaurna/ af Accauntancy, (September). 93-97.

Hall, M.C., and K.M. Elliott (1993). Expectations and performance From Whose Perspective : A note on measuring service quality, Jaurna/ af Prafessiona/ Service Marketing 8(2):27-32.

Handi Irawan, (2000). "Mengukur Lustamer Satisfaction Sejak Dini". Bisnis Indonesia, Jum'at, 25 Februari.

Harry Suharta, (200Z), Quality Control PPA, IAI Mampu Menjamin Kualitas, Media Akuntansi, Edisi 24/ Maret/ Tahun IX.

H.S. Munawir(1997), Auditing Madern, Buku I BPFE, Yogyakarta,

Ikatan Akuntan Indanesia, 200I. Standar Profesiona/ Akuntan Publik. Per I Januari, Penerbit Saleba Empat.

Imam Ghozali (20DI), Aplikasi Analisis Multivariate dengan Program SPSS, BP UNDIP, Semarang.

J. Supranto (1997). Pengukuran Tingkat Kepuasan Pelanggan," Bhinika Cipta."

Mahon, James ل. (1988Z). The Marketing of Pprofessiana/Accaunting Service, $2^{2 d}$ ed., Jahn Wiley \& Sans, Canada.

Mautz, R.K. and Hussein A. Sharaf (ISGI). The Philosaphy of Auditing, AAA, Florida.

Menon, Krishnagapal and Joanne Deahl Williams (1994). The Use of Auditt Committees far Monitoring, Jaurna/ of Accounting and Public Policy, vol. 13:121-139..

Mock, T.J., and M. Samet (1982). A Multi Attribute Made/ far Audit Evaluation, in Proceedings of the VI University of Kansas Audit Symposium.

Muhammad Ishak, (2000), Analisis Faktor-Faktor Penentu Kualitas Audit Menurut Persepsi Klien, Tesis UGM (Tidak di Publikasikan).

Neni Meidawati (200I), Meningkatkan Akuntabilitas Auditor Independen Melalui Standar Profesional, Media Akuntansi Edisi I6-Januari-Februari-Tahun 8.

Parasuraman, A., Valeri A. Zeithmal, and Leonard L. Веггy (1985). Problem and Strategis in Service Marketing. Jaurnal of Marketing (Spring). Vol 49.38-46.

Pramudianti, M. (2014), Analisis Pengaruh Atribut-Atribut Kualitas Audit Terhadap Kepuasan Klien (Studi Pada Perusahaan Manufakturmyang Terdaftar di Bursa Efek Indanesia, Equilibrium, Valumen 12, Namar I, April, Hal. $39-53$.

Purwono, Angga Styo (20II), Pengaruh Atribut Kualitas Audit Terhadap Kepuasan Klien (studi Empiris Bank Perkreditan Rakyat di Jawa Tengah), Skripsi Fakultas Ekanami UNDIP.

Schroeder, M.S., I. Saloman, and D.W. Vickrey (1986) Audit Euality: The Perception of Audit Cammittee Chairpersons and Audit Partners, Auditing : A Jaurna/ of Practice \& Theory 5. (Spring):86-94. 
Sutton, S.G. (1993). Toward an Understanding of the Factors Affecting the Quality of the Audit Process, Decision Sciences 24:80-105.

Taylar, S.A., and TT. Baker (1994). An Assesment of the Relationship between Service Quality and Customer Satisfaction in the Formation of Consumer's Purchase Intentions, Jaurna/ of Retailing 7D (2):I63-178.

Tubb, Richard M. (1992) The Effect of Experience on the Auditars Drganization and Amount of Knowledge, The Accounting review, (Dctober), vol. 67, по. 4:783-801.

Tatang, Manajemen dan Lsahawan Indanesia, №. O6/Th XXIV/ Juni 1995.

Tim, Media Akuntansi(1998), Penelitian Kepuasan Klien dari Masa ke Masa : Belum Menjawab Kebutuhan, №. 25/ Th. V. / Maret..

Widagda, Ridwan, Lesmana, Sukma., dan Irwandi, Soni Agus, 2002. Analisis Pengaruh Atribut-Atribut Kulaitas Audit Terhadap Kepuasan Klien (Studi Empiris Pada Perusahaan yang Terdaftar di Bursa Efek Jakarta). Simpasium Nasiona/ Akuntansi 5, Semarang. 5-6 September, Hal. 560 - 574.

Widagda, Ridwan, 2002. Atribut-Atribut Kualitas Audit, لlurna/ Riset Akuntansi Indanesia.

Wolk, Carel M. and Charles W. Woatton. 1997. Handling the Small Public Audit Client. Jaurna/ af Accauntancy. (May): 53-57.

Woudruff (1997)," Customer Value:The Next Source for Competitive Advantage," Jaurna/ af The Academic of Marketing Science, Vol.25, No.2, Pages I39-153. 